\title{
Epidemiology of Opportunistic Pathogen Nontuberculous Mycobacteria in a Referral Hospital in Ankara
}

\section{Ankara'da bir Referans Hastanede Fırsatçı Patojen Tüberküloz Dıșı Mikobakterilerin Epidemiyolojisi}

\author{
İsmail CEYHAN' (ID), Sedat VEZIR² (IID) \\ ${ }^{1}$ Department of Nursing, Ankara Yildirim Beyazit University Faculty of Health Sciences, Ankara, Turkey \\ ${ }^{2}$ Microbiology and Tuberculosis Laboratory, Atatürk Chest Diseases and Chest Surgery Training and Research Hospital, Ankara, Turkey \\ Cite this article as: Ceyhan i, Vezir S. Epidemiology of opportunistic pathogen nontuberculous mycobacteria in a referral hospital in Ankara. FLORA \\ 2021;26(4):670-8.
}

\begin{abstract}
Introduction: Non tuberculous mycobacteria (NTM) have been isolated more frequently from clinical cases in recent years. The aim of this study was to show the distribution and identification of NTM isolated from pulmonary samples of patients pre-diagnosed as tuberculosis between 2010-2019 in a referral tuberculosis hospital by commercial Line Probe Assay (LPA, GenoType MycobacteriumCM/ AS, Hain Lifescience, Nehren Germany).
\end{abstract}

Materials and Methods: A total of 528 NTM strains obtained from pulmonary samples of 47.161 suspected tuberculosis (TB) patients were included in the study. The samples were processed by routine methods (homogenization-decontamination, acid-fast staining and culture) in the laboratory according to previously described reference procedures. DNA isolation from acid-fast bacilli and LPA GenoType assay were performed and evaluated according to the manufacturer's recommendations.

Results: In the study, the most common species were found a Mycobacterium avium complex (MAC), Mycobacterium fortuitum, Mycobacterium abscessus and Mycobacterium chelonae, with a rate of 35.7\%, 18.6\%, 16.0\%, and 11.2\% respectively. Mycobacterium szulgai/Mycobacterium intermedium, Mycobacterium kansasi, Mycobacterium simiae were isolated at the rate of 5.2\%, 4.3\% and $3.0 \%$ respectively, while Mycobacterium lentiflavum, Mycobacterium celatum, Mycobacterium mucogenicum and Mycobacterium asiaticum were less than $1.0 \%$.

Conclusion: Our study showed that LPA method, The GenoType ${ }^{\circledR}$ Mycobacterium CM/AS assay, which uses multiplex PCR and reverse hybridization, is an useful tool for rapid diagnosis of mycobacteria isolated from suspected TB patients in a routine hospital laboratory and has a good potential to show epidemiological distribution of NTM.

Key Words: Line probe Assay; Nontuberculous mycobacteria; Epidemiology of nontuberculous mycobacteria; Pulmonary disease 


\title{
öz
}

\section{Ankara'da bir Referans Hastanede Fırsatçı Patojen Tüberküloz Dıșı Mikobakterilerin Epidemiyolojisi}

\author{
İsmail CEYHAN', Sedat VEZIR²
}

\footnotetext{
${ }^{1}$ Ankara Yıdırım Beyazıt Üniversitesi Sag̃lık Bilimleri Fakültesi, Hemșirelik Bölümü, Ankara, Türkiye

2 Atatürk Gögüs Hastalıkları ve Gög̃üs Cerrahisi Eg̃itim ve Araștırma Hastanesi, Mikrobiyoloji ve Tüberküloz Laboratuvarı, Ankara, Türkiye
}

Giriș: Son yıllarda tüberküloz dışı mikobakteriler (TDM) klinik vakalardan daha sık izole edilmektedir. Bu çalışmanın amacı, 2010-2019 yılları arasında bir tüberküloz referans hastanesinde akciğer tüberkülozü ön tanısı alan hastaların pulmoner örneklerinden izole edilen TDM'lerin ticari Line Prob Assay (LPA, GenoType Mycobacterium CM/AS, Hain Lifescience, Nehren) testiyle tanımlanması ve tür dağılımının gösterilmesidir.

Materyal ve Metod: Toplam 47.161 şüpheli tüberküloz (TB) hastasının pulmoner örneklerinden elde edilen toplam 538 TDM suşu çalışmaya dahil edildi. Numuneler laboratuvarda daha önce tanımlanan rutin referans yöntemlerle (homojenizasyon-dekontaminasyon, aside dirençli boyama ve kültür) işlendi. Aside dirençli basilden (ARB) DNA izolasyonu ve LPA GenoType testi üreticinin önerilerine göre yapıldı ve değerlendirildi.

Bulgular: Çalışmada en yaygın türler Mycobacterium avium kompleksi (MAC), Mycobacterium fortuitum, Mycobacterium abscessus ve Mycobacterium chelonae sırasıyla \%35.7, \%18.6, \%16.0, and \%11.2 oranında bulunmuştur. Mycobacterium szulgai/Mycobacterium intermedium, Mycobacterium kansasi, Mycobacterium simiae sırasıla \%5.2, \%4.3 ve \%3.0 oranlarında iken Mycobacterium lentiflavum, Mycobacterium celatum, Mycobacterium mucogenicum ve Mycobacterium asiaticum \%1.0'den daha az olarak izole edilmiştir.

Sonuç: Çalışmamı, ticari multipleks PCR ve ters hibridizasyon kullanan LPA GenoType ${ }^{\circledR}$ Mycobacterium CM/AS testinin, rutin bir hastane laboratuarında şüpheli TB hastalarından izole edilen mikobakterilerin hızlı teşhisi için yararlı bir araç olduğunu ve TDM'nin epidemiyolojik dağılımının gösterilmesinde iyi bir potansiyele sahip olduğunu göstermiştir.

Anahtar Kelimeler: Line probe assay; Tüberküloz dışı mikobakteriler; Tüberküloz dışı mikobakterilerin epidemiyolojisi; Akciğer hastalığı

\section{INTRODUCTION}

Non tuberculous mycobacteria (NTM) have been isolated more from clinical cases in recent years. Mycobacterium other than Mycobacterium tuberculosis complex (MTBC) are mostly called "non tuberculosis mycobacteria" or atypical mycobacteria. Most of the NTM are commonly found in nature and are known as opportunistic pathogens ${ }^{[1,2]}$. Mycobacteria are divided into two main groups as rapid and slow growers depending on their growth rate on laboratory media. The rapidly growing mycobacteria (RGM) are generally grown within 7 days. Conversely, NTM requiring more than 7 days to form visible colonies on the media are named "slowly growing mycobacteria ${ }^{[2] . "}$

Identification of NTM is essential not only for the treatment of NTM diseases in individuals but also for monitoring its epidemiological trend and distribution of species. Appropriate diagnosis of NTM infections by acid-fast staining and biochemical tests are not sufficient, and classical tuberculosis drugs are mostly unsuccessful for these patients ${ }^{[3]}$. Definintion of non-tuberculosis mycobacteria species is critical for successful treatment and must be performed since treatment is almost always based on kind of Mycobacterium spp. $[2,4-7]$

Cultural and biochemical characteristics were used in the differentiation of many mycobacteria species before molecular tests were introduced. Even though some phenotypic characteristics are still being used today in some laboratories, advanced and molecular methods have often been preferred for more than two decades. One of these methods, Line Probe Assay (LPA), is now widely used for rapid and accurate identification of mycobacteria lately. To identify frequently isolated ones from clinical samples of Mycobacterium species, LPA, a genetic strip technique based 
on the application of PCR plus reverse-hybridization DNA, has been developed. In general, mycobacterial 16-23S rRNA spacer region from isolated strains growing on solid or in liquid media are amplified using PCR with biotinylated primers. Subsequently, obtained PCR products are hybridized to nitrocellulose membrane-bound species-specific fragments on a strip followed by an enzyme-mediated colour reaction. The species-specific banding patterns are visually analysed following a colorimetric conjugation step by comparison to a commercially available chart which is coded to the NTM species identification ${ }^{[3]}$.

LPA can be run from solid or liquid media, and results are available in hours, depending on the type of strips. More than 90\% of the commonly encountered mycobacteria can be identified by LPA. There are few reports of misidentifications that have been described for line probe assays, and they usually occur for the less commonly encountered species ${ }^{[3-8]}$.

Almost $90 \%$ of NTM diseases show clinical picture as chronic pulmonary disease. Other NTM are related to extrapulmonary infections including skin, soft tissue, lymphadenitis, and disseminated infection. Depending on host vulnerability and pathogenicity of the causative agent, disease progression can be variable. Some factors facilitate the formation of the disease, such as bronchiectasis, chronic obstructive pulmonary disease, and immunosuppression ${ }^{[9,10]}$.

In this study, we aimed to perform species identification and distribution of NTM isolated from the pulmonary samples of patients pre-diagnosed as tuberculosis between 2010-2019 in a referral hospital in Turkey by a commercial polymerase chain reaction (PCR) based reverse hybridization kit LPA, GenoType assay (Hain Lifescience, Nehren Germany).

\section{MATERIALS and METHODS}

\section{Mycobacteria Isolates}

Retrospective study was conducted in one of four referral tuberculosis (TB) hospital in Turkey, involving suspected TB patients with a positive cultural exam for NTM over a period of ten years from 2010 to 2019, detected in any collected pulmonary samples including lung biopsy.
Trend analysis for species were not analysed in this study. NTM disease was diagnosed based on American Thoracic Society (ATS). A "possible case" was defined as a person with at least one positive pulmonary mycobacterial isolate other than Mycobacterium tuberculosis or Mycobacterium gordonae. A "definite case" further met additional ATS microbiologic criteria at least two sputum samples positive for an NTM species or a single positive culture from bronchoscopy or lung biopsy.

The patients excluded from this study were those with unspecified Mycobacterium spp. isolates. As pulmonary samples, 185.634 sputum and 30.009 bronchoalveolar lavage including bronchial aspiration were processed. A total of 538 NTM strains obtained from pulmonary samples of 47.161 suspected TB patients were included in the study. The samples were processed according to commonly used and previously described routine methods ${ }^{[11]}$. The samples were processed by homogenization-decontamination, acid-fast staining and inoculated into at least one solid medium (Löwenstein-Jensen and/or Ogawa) and in an automated culture system (BACTEC/ MGIT 960, USA or VersaTREC, Trec Diagnostics, UK ). 19.541 suspected TB patients yielded mycobacterial growth in their cultures.

\section{GenoType assay (Line probe assay method, LPA)}

GenoType assay (GenoType ${ }^{\circledR}$ Mycobacterium CM/AS, Hain Lifescience, Nehren Germany) is based on the detection of species-specific sequence in the 23S rRNA gene. There are two kits - the CM, which identifies 15 Mycobacterium spp, including MTBC while the AS kit aims to differentiate 16 additional less common NTM species available for differentiation. In general, the target sequences from culture are amplified using PCR and biotinylated primers. Subsequently, the amplified PCR products are hybridized to nitrocellulose membrane-bound species-specific fragments on a strip followed by an enzyme-mediated colour reaction. The specific banding patterns are visually analysed following a colorimetric conjugation step by comparison to a chart that is coded to the NTM species identification. 
The GenoType CM assay identifies Mycobacterium avium, Mycobacterium chelonae, Mycobacterium abscessus, Mycobacterium fortuitum complex, Mycobacterium gordonae, Mycobacterium intracellulare, Mycobacterium scrofulaceum, Mycobacterium interjectum, Mycobacterium szulgai, Mycobacterium kansasii, Mycobacterium malmoense, Mycobacterium peregrinum and Mycobacterium xenopi as common NTM species and MTBC, but is unable to discriminate between the Mycobacterium marinum/Mycobacterium ulcerans according to the manufacturer. The AS strip can identify additional species including Mycobacterium simiae, Mycobacterium mucogenicum, Mycobacterium goodii, Mycobacterium celatum, Mycobacterium smegmatis, Mycobacterium genavense, Mycobacterium lentiflavum, Mycobacterium heckeshornense, Mycobacterium szulgai, Mycobacterium intermedium, Mycobacterium phlei, Mycobacterium haemophilum, Mycobacterium kansasii, M. ulcerans, Mycobacterium gastri, Mycobacterium siaticum and Mycobacterium shimoidei (Table 1).

In the study, MTBC strains were identified and excluded by using cart test (MPB64, Capilla TB-Neo, Tauns Laboratories, Inc., Numazu, Japan) including some phenotypic characteristic such as cord factor in liquid or colony morphology on solid media, where applicable. The GenoType Mycobacterium CM/AS assay was performed as recommended by the manufacturer. Briefly, DNA were isolated from the culture and PCR method was performed by using the primers specific for mycobacterial 23S rRNA spacer region. PCR products were then hybridized with the probes specific for Mycobacterium species on nitrocellulose strips. For colorimetric detection of hybridized amplicons, streptavidin conjugated with alkaline phosphatase and substrate buffer was added. After final washing, strips were air dried and fixed on paper. Patterns were evaluated in accordance with the reference card provided by the manufacturer.

\section{RESULTS}

In this study, as pulmonary samples, sputum (86.1\%) and bronchial aspiration fluid/ bronchoalveolar lavage (13.9\%) were processed, and 13 different Mycobacterium spp. were found. In the study, pulmonary samples from 19.541 suspected TB patients yielded mycobacterial growth in their cultures, and $538(2.8 \%)$ were identified as NTM. Only 20 (3.7\%) of the isolated mycobacteria could not be identified by this method, so they remained as Mycobacterium spp. NTM were isolated from the culture of 1098 respiratory tract samples belonging to 538 patients. While repeated atypical mycobacterial growth was found in 413 patients on $\geq 2$ different days, 125 patients showed NTM growth in at least one sample (bronchial aspiration fluid and bronchoalveolar lavage including lung biopsy) or in separate multiple samples taken within the same day. We excluded the isolates that were thought to be laboratory or environmental contamination according to ATS criteria.

Species distribution was as follows; $M$. avium $(\mathrm{n}=101,18,8 \%)$, M. fortuitum $(\mathrm{n}=100,18.6 \%)$, M. intracellulare $(\mathrm{n}=91,16.9 \%), M$. abscessus $(\mathrm{n}=86,16.0 \%), M$. chelonae $(\mathrm{n}=60,11.2 \%)$, M. szulgai/M. intermedium ( $\mathrm{n}=28,5.2 \%), M$. kansasii $(\mathrm{n}=23,4.3 \%), M$. smiae $(\mathrm{n}=16,3.0 \%)$, M. celatum $(\mathrm{n}=3,0.6 \%), M$. lentiflavum $(\mathrm{n}=3$, $0.6 \%)$, M. malmoense $(\mathrm{n}=3,0.6 \%), M$. mucogenicum $(\mathrm{n}=3,0.2 \%)$, and $M$. asiaticum $(\mathrm{n}=1$, $0.2 \%)$. Only $20(3.7 \%)$ NTM isolated from the patients could not be identified with this method (Figure 1). Table 2 shows the isolated Mycobacterium species by GenoType ${ }^{\circledR}$ Mycobacterium CM/

\section{Table 1. Identification of Nontuberculous Mycobacteria (NTM) by GenoType ${ }^{\circledR}$ Mycobacterium CM and} AS

CM M. tuberculosis complex, M. avium, M. chelonae, M. abscessus, M. fortuitum, M. gordonae, M. intracellulare, M. scrofulaceum, M. interjectum, M. kansasii, M. malmoense, M. marinum, M. ulcerans, M. peregrinum, M. xenopi and Mycobacterium spp.

AS M. simiae, M. mucogenicum, M.goodii, M. celatum, M. smegmatis, M. genavense, M. lentiflavum, M. heckeshornense, M.szulgai, M. intermedium, M. phlei, M. haemophilum, M. kansasii, M. ulcerans, M. gastri, M.asiaticum and M. shimoidei 


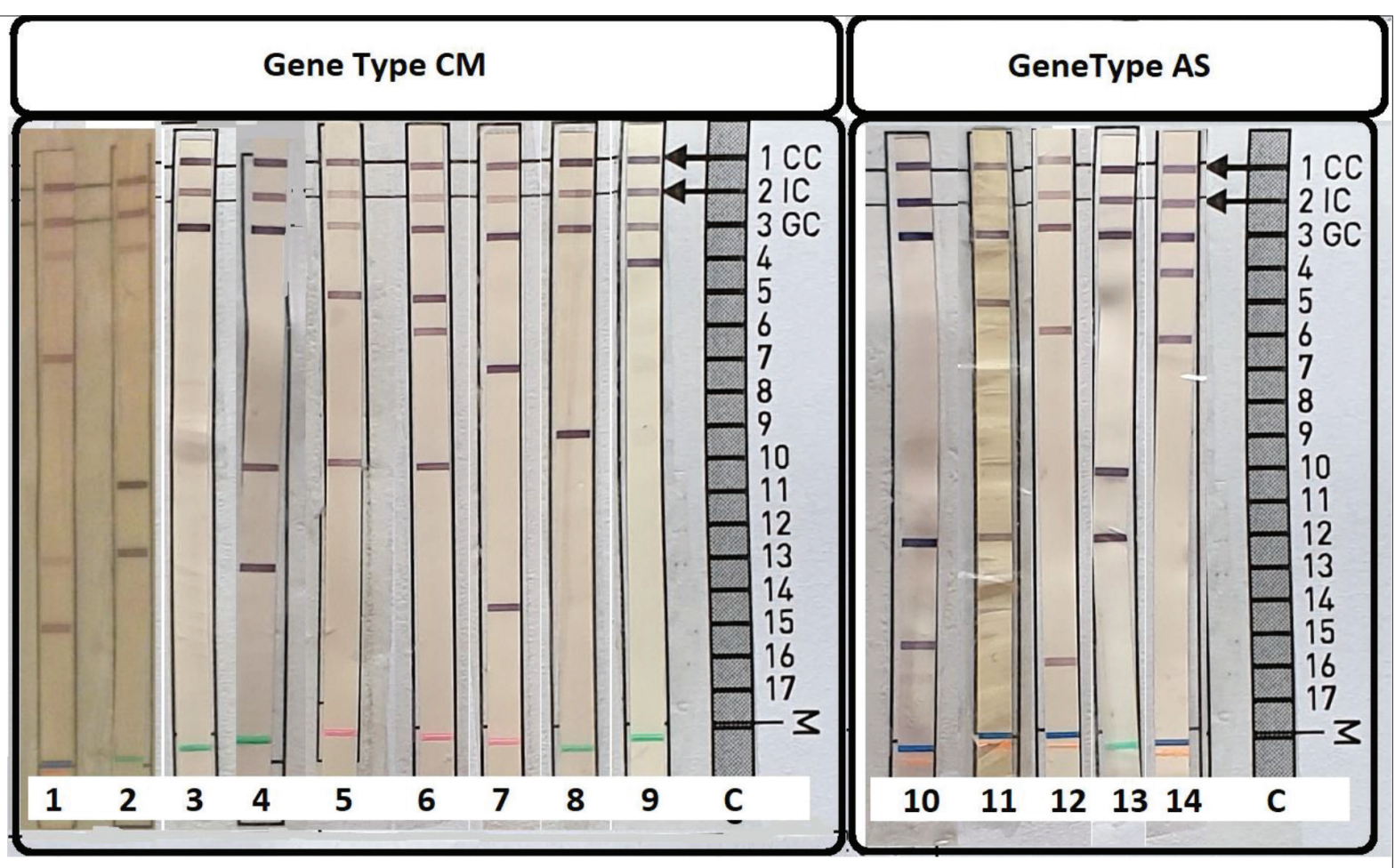

Figure 1. GenoType ${ }^{\circledR}$ mycobacterium common mycobacteria/additional species (CM/AS) assay (Hain Lifescience, Nehren Germany) for rapid differentiation of different species of Mycobacteria. (1) Mycobacterium celatum, (2) Mycobacterium kansasii, (3) Mycobacterium spp, (4) Mycobacterium malmoense, (5)Mycobacterium chelonae, (6) Mycobacterium abscessus, (7) Mycobacterium fortuitum, (8) Mycobacterium intracellulare, (9) Mycobacterium avium, (10) Mycobacterium asiaticum, (11) Mycobacterium mucogenicum, (12) Mycobacterium lentiflavum, (13) Mycobacterium szulgai/ Mycobacterium intermedium, and (14) Mycobacterium smiae.

CC: Conjugate Control, IC: Internal Control, GC: Genus Control, C: Chart for line corresponding species. M:Marker line

Table 2. Distribution of different NTM species differentiated by GenoType ${ }^{\circledR}$ Mycobacterium CM/AS assay $(n=538)$

\begin{tabular}{lc}
\hline Species & Frequency (\%) \\
\hline M. avium & $101(18.8 \%)$ \\
M. fortuitum & $100(18.6 \%)$ \\
M. intracellulare & $91(16.9 \%)$ \\
M. abscessus & $86(16.0 \%)$ \\
M. chelonae & $60(11.2 \%)$ \\
M. szulgai/M. intermedium & $28(5.2 \%)$ \\
M. kansasii & $23(4.3 \%)$ \\
M. smiae & $16(3.0 \%)$ \\
M. celatum & $3(0.6 \%)$ \\
M. lentiflavum & $3(0.6 \%)$ \\
M. malmoense & $3(0.6 \%)$ \\
M. mucogenicum & $3(0.6 \%)$ \\
M. asiaticum & $1(0.2 \%)$ \\
Mycobacterium spp. & $20(3.7 \%)$ \\
&
\end{tabular}


AS assay (Hain Lifescience, Nehren Germany) in the study.

\section{DISCUSSION}

Unlike $M$. tuberculosis, most mycobacteria other than tuberculosis and leprae are not obligate pathogens. The majority of NTM are widespread in nature free-living organisms such as soil, water, and so on ${ }^{[1,2]}$. However, they have been frequently reported in clinical cases in recent years ${ }^{[8,10]}$.

Identification of isolated Mycobacterium from clinical samples is important as the species differ in virulence, useful drugs for therapy, host range and ecology. According to regional data obtained from different studies, the most frequent strains seem to be found in clinical cases were MAC, M. kansasii, M. malmoense, M. abscessus, M. chelonae and M. fortuitum. Many NTM are not only capable of causing infections in immunosuppressed people but also cause infections in some immunocompetent individuals ${ }^{[4-7]}$.

Commonly used acid-fast staining for the diagnosis of tuberculosis is not able to distinguish between TB and NTM. Because biochemical methods are also insufficient to distinguish most of the mycobacteria, using this method is not recommended ${ }^{[12,13]}$. Attempts to treat NTM patients with anti-TB drugs almost always fail and lead to worsening. This also leads to unnecessary use of drugs, prolonged hospitalization, and economic losses $^{[12]}$. For more accurate identification of NTM in place of biochemical methods, some routine and research laboratories used methods based on chromatographic/chemotaxonomic methods including high-performance liquid chromatography (HPLC). However, newer, advanced and molecular diagnostic methodologies have been introduced for rapid and accurate diagnosis of NTM lately. These methods are based on the detection of certain gene regions such as 16S-23S rRNA, hsp65, recA, rpoB, which vary among mycobacterial species. Sufficient identification of the species can be achieved by replicating the target genetic region and determining the differences. One of these methods, LPA, is based on the application of PCR plus reverse-hybridization DNA for identifying a variety of species of $\mathrm{NTM}^{[3]}$.

Studies on the distribution of NTM infections in Turkey are very limited ${ }^{[10]}$. The aim of this study was to identify NTM by LPA method and to show the species-level distribution of NTM isolated from persons with lung infection in a referral hospital. Bicmen et al. have found that LPA method is specific enough and fast for more frequently isolated NTM species ${ }^{[12]}$. The method that we also used in our study is now being used in many EU countries for either as a screening test or routine identification of $\mathrm{NTM}^{[14]}$. In this study, we identified thirteen different opportunistic pathogen mycobacterial species by the GenoType assay (Table 2).

Prevalence of NTM among suspected TB cases ranges from $5.5 \%-47 \%$ in North America, from $4 \%-15 \%$ in the Middle East and Africa and $0.2 \%-3.1 \%$ in Europe. MAC is the most isolated agent worldwide, especially in East Asia and North America including the United States. A populationbased estimate of trends in NTM pulmonary disease in the United States using current ATS microbiologic criteria has demonstrated an overall increasing rate of pulmonary NTM (5.5\%). MAC was the most commonly isolated species from patients with a definite case of pulmonary NTM at the rate of $80 \%$. The next most common group was the rapidly growing mycobacteria $(M$. chelonae/M. abscessus or M. fortuitum), and their frequency was more variable across sites, ranging from $5.2-19.2 \%[15]$.

The rate of NTM isolation from different studies has been found as follows: The United Kingdom, over 1995-1999, approximately $1.7 \%$, and in Central Greece, over 2004-2006, $0.7 \%{ }^{[16,17]}$. The Nijmegen-Arnhem region of the Netherlands has been extensively studied. Researchers reported, over 1999-2005, that the rate of NTM was $1.4 \%[18]$. Detailed analysis of NTM epidemiology throughout Denmark over 1997-2008 reported the rate of NTM disease as $1.1 \%{ }^{[19]}$ The NTM rate we found $(2.8 \%)$ in this study was close and slightly high in most of European countries, but it was different from studies in the United States ${ }^{[10]}$. 
Distribution of MAC in European countries varies (22.4\%-82.0\%) by regions or countries. $M$. kansasii, M. malmoense and $M$. xenopi are also common in Europe $e^{[10]}$. Studies from France for estimation of NTM distribution across the country have used a sentinel-site methodology, collecting data over 2000-2003, from 32 sites ${ }^{[20,21]}$. According to the estimation, NTM distribution was MAC (48\%), M. xenopi (25\%), M. kansasii (13\%) and $M$. abscessus $(9 \%)$ respectively ${ }^{[21]}$. In the UK, among 117 patients with NTM pulmonary disease over 1995-1999, species distribution was MAC first (45\%), followed by $M$. malmoense (37\%), $M$. xenopi $(6 \%)$ and $M$. kansasii $(6 \%)^{[16]}$. The most frequently isolated opportunistic pathogenic species from pulmonary diseases in our study were MAC (35.7\%), M. fortuitum (18.6\%), $M$. abscessus (16.0\%) and $M$. chelonae (11.2\%), respectively. We found the most common NTM in our hospital as MAC, the same as in most studies in Europe and in the United States. M. kansasii was found as the second most common agent in the United States, Europe and South Africa $^{[2]}$. In our study, however, we found that $M$. kansasii (4.3\%) ranked sixth, after M. szulgai/M. intermedium (5.2\%).

Bicmen et al. evaluated the distribution of NTM detected in their own hospital laboratory in Turkey between 2004 and 2006, and MAC was found the most frequently isolated species with a rate of $26.6 \%$. In the same study, the researchers detected $M$. fortuitum/peregrinum complex, M. chelonae compleks, M. gordonae, M. kansasii, Mycobacterium spp, M. szulgai/ intermedium, $M$. simiae, and $M$. scrofulaceum at the rates of $16.7 \%, 13.3 \%, 13.3 \%, 10 \%, 6.7 \%$, $6.7 \%$, and $3.3 \%$, respectively. One of the most important findings of the study was that the method works very well in mixed cultures ${ }^{[12]}$. In another study conducted in the country, 75 NTM were determined in 101 samples collected from 15 different institutions in 2009-2010. The more frequently isolated NTM species in pulmonary and non-pulmonary samples were found $M$. fortuitum $(33.3 \%, \mathrm{n}=25), M$. abscessus $(18.7 \%, \mathrm{n}=14)$, $M$. gordonae $(10.7 \%, \mathrm{n}=8)$ and $M$. avium $(8 \% ; n=6)^{[22]}$. Gunaydin et al. have identified 17 different species obtained from a total of ninety NTM from four different centres located in Turkey. Contrary to the findings we found in our research, M. gordonae (23.3\%), M. abscessus (14.4\%) and $M$. lentiflavum (10\%) have been reported as the three most common species by Gunaydin et al. ${ }^{[23]}$. Some Mycobacterium species such as $M$. gordonae have been reported as pathogenic agents by Gunaydin et al. and Albayrak et al., but we mostly identified them as the environmental contaminant according to ATS.

The results of many studies conducted in the world have shown heterogeneous epidemiology of NTM isolations and NTM disease worldwide. The available data about distribution of NTM is very different from continent to continent, from country to country and even within countries ${ }^{[10,24]}$. Our study has several limitations. Firstly, our study was only performed on suspected pulmonary TB patients and evaluation of our case definition is limited. Thus, we used "definite case" as microbiologic criteria alone. Secondly, the GenoType assay we used in the study is unable to discriminate between some NTM groups such as $M$. intracellulare/M. chimaera, $M$. malmoense/M. haemophilum/M. palustre/M. nebraskense, and MTBC/M. xenopi. Recent studies also show that the GenoType M. intracellulare probe crosshybridizes with several other NTM including $M$. arosiense, M. chimaera, M. colombiense, and M. mantenii in the "MAC X" complex and $M$. saskatchewanense $^{[3]}$.

To conclude, our study, similar to previous studies, ${ }^{[2,10]}$ showed that MAC was the most common mycobacteria isolated pulmonary infection among our patients. We evaluated that the proportional differences between mycobacteria isolated from those patients may be due to sample numbers, limitations of the methods and/or geographic differences. Despite inherent limitations, the species found in this study and their frequencies probably reflect the current epidemiological situation for NTM in the Turkey. In addition, our study showed that LPA method, The GenoType ${ }^{\circledR}$ Mycobacterium $\mathrm{CM}$ /AS assay, which uses multiplex PCR and reverse hybridization, is a useful tool for rapid diagnosis of mycobacteria isolated from suspected TB patients in a routine hospital laboratory and 
has a good potential to show epidemiological distribution of NTM.

\section{ACKNOWLEDGEMENT}

We thank Nafia Ozturk, Resul Altınsoy and all the other technicians for their technical contributions in Laboratory in Ataturk Chest Diseases and Chest Surgery Training and Research Hospital, Ankara, Turkey.

\section{ETHICS COMMITTEE APPROVAL}

The study was approved by the Ethics Committee of Ankara Yildirim Beyazit University (09/11/2020-29).

\section{CONFLICT of INTEREST}

None of the authors had conflict of interest.

\section{AUTHORSHIP CONTRIBUTIONS}

Concept and Design: All of authors

Data Collection or Processing: All of authors

Analysis/Interpretation: All of authors

Literature Search: All of authors

Writing: İC

Final Approval: All of authors

\section{REFERENCES}

1. Pfyffer GE. Mycobacterium: General Characteristics, Laboratory Detection, and Staining Procedures. In: Jorgensen JH, Pfaller MA (eds). Manual of Clinical Microbiology. Washington DC: ASM Press, 2015:536-569.

2. Griffith $D E$, Aksamit $T$, Brown-Elliott BA, Catanzaro $A$ Delay C, Gordin F, et al. An official ATS/IDSA statement: Diagnosis, treatment, and prevention of nontuberculous mycobacterial diseases. Am / Respir Crit Care Med 2007 175:367-416.

3. Brown-Elliott BA. Laboratory diagnosis and antimicrobial susceptibility testing of nontuberculous mycobacteria. In: Griffith DE (eds) Nontuberculous Mycobacterial Disease, Humana, Switzerland, 2019:15-59.

4. Wassilew N, Hoffmann H, Andrejak C, Lange C. Pulmonary Disease Caused by Non-Tuberculous Mycobacteria. Respiration 2016;91:386-402.

5. Jun HJ, Jeon K, Um SW, Kwon OJ, Lee NY, Koh WJ. Nontuberculous mycobacteria isolated during the treatment of pulmonary tuberculosis. Respir Med 2009;103:1936-40.

6. Kang YA, Koh WJ. Antibiotic treatment for nontuberculous mycobacterial lung disease. Expert Rev Respir Med 2016;10:557-68.
7. Piersimoni C, Scarparo C. Pulmonary infections associated with non-tuberculous mycobacteria in immunocompetent patients. Lancet Infect Dis 2008;8:323-34.

8. Simner PJ, Woods GL, Wengenack NL. Mycobacteria. Microbiol Spectrum 2016;4(4)DMIH2-0016-2015.

9. Drummond WK, Kasperbauer SH. Nontuberculous mycobacteria epidemiology and the impact on pulmonary and cardiac disease. Thorac Surg Clin 2019;29:59-64.

10. Prevots DR, Marras TK. Epidemiology of human pulmonary infection with nontuberculous mycobacteria. Clin Chest Med 2019;36:13-34.

11. European Centre for Disease Prevention and Control. Handbook on tuberculosis laboratory diagnostic methods in the European Union Updated 2018. Stockholm: ECDC; 2018.

12. Bicmen C, Coskun M, Gunduz AT, Senol G, Cirak AK, Tibet G. Identification of atypical mycobacteria isolated from clinical specimens by line probe assay (LIPA). Mikrobiyol Bul 2007; 41:503-10.

13. Somoskovi A., Mester J, Hale YM, Parsons LM, Salfinger M. Laboratory diagnosis of nontuberculous mycobacteria. Clin Chest Med 2002;23:585-59.

14. van der Werf MJ, Ködmön C, Katalinić-Janković V, Kummik $T$, Soini $H$ Richter $E$, et al. Inventory study of non-tuberculous mycobacteria in the European Union. BMC Infect Dis 2014;14:62.

15. Prevots $D R$, Shaw $P A$, Strickland $D$, Jackson $L A$, Raebel $M A$, Blosky MA, et al. Nontuberculous mycobacterial lung disease prevalence at four integrated health care delivery systems. Am J Respir Crit Care Med 2010;182:970-6.

16. Henry MT, Inamdar $L$, O'Riordain D, Schweiger $M$, Watson JP. Nontuberculous mycobacteria in non-HIV patients:Epidemiology, treatment and response. Eur Respir I 2004;23:741-6.

17. Gerogianni I, Papala M, Kostikas K, Petinaki E, Gourgoulianis KI. Epidemiology and clinical significance of mycobacterial respiratory infections in Central Greece. Int I Tuberc Lung Dis 2008;12:807-12.

18. van Ingen J, Bendien SA, de Lange WCM, Hoefsloot W, Dekhuijzen PNR, Boeree MJ et al Clinical relevance of nontuberculous mycobacteria isolated in Nijmegen-Arnhem region, The Netherlands. Thorax 2009;64:502-6.

19. Andrejak C, Thomsen VO, Johansen IS, Riis A, Benfield TL, Duhaut $P$, et al. Nontuberculous pulmonary mycobacteriosis in Denmark: incidence and prognostic factors. Am J Respir Crit Care Med 2010;181:514-21.

20. Maugein J, Dailloux M, Carbonelle B, Vincent V, Grosset J. Sentinel site surveillance of Mycobacterium avium complex pulmonary disease. Eur Respir J 2005;26:1092-6.

21. Dailloux M, Abalain ML, Laurain C, Lebrun L, Loos-Ayav C, Lozniewski $A$, et al. Respiratory infections associated with nontuberculous mycobacteria in non-HIV patients. Eur Respir J 2006;28:1211-5. 
22. Albayrak N, Simsek $H$, Sezen F, Aslanturk A, Tarhan G, Ceyhan I. Evaluation of the distribution of non-tuberculous Mycobacteria strains isolated in National Tuberculosis Reference Laboratory in 2009- 2010, Turkey. Mikrobiyol Bul 2012;46:560-7.

23. Gunaydin M, Yanık K, Eroğlu C, Sanic A, Ceyhan I, Erturan $Z$ et al. Distribution of Nontuberculous Mycobacteria strains. Annals of Clinical Microbiology and Antimicrobials 2013;33:1-6.

24. Wagner D, Lipman M, Cooray S, Ringshausen FC, Morimoto K, Koh WJ et al. Global Epidemiology of NTM Disease (Except Northern America). In: Griffith DE (ed). Nontuberculous Mycobacterial Disease. Humana, Switzerland 2019:163-260.

\section{Address for Correspondence/Yazıșma Adresi}

Dr. İsmail CEYHAN

Ankara Yıdırım Beyazıt Üniversitesi,

Sağlık Bilimleri Fakültesi,

Hemșirelik Bölümü,

Ankara-Türkiye

E-posta: isceyhan@gmail.com 